\title{
1984 年長野県西部地震による斜面崩壊とその特徵
}

\author{
大草重 康*. 安間 荘**. 毎熊 弘** \\ 藤田至則***. 粐倉克幹****
}

\section{Slope Failures and Debris Flow Characteristics during the 1984 Naganoken-Seibu Earthquake}

\author{
Shigeyasu OKUSA, So ANMA, Hiromu MAIKUMA, \\ Yukinori FUJITA and Yoshimasa MOMIKURA
}

\begin{abstract}
On September 14, 1984, an earthquake of magnitude 6.8 (Richter) occurred at a depth of $2-3 \mathrm{~km}$ near an active volcano, Mt. Ontake $(3063 \mathrm{~m})$, in the mountainous area of central Japan.

The geology of the mountain is Quaternary pyroclastic rocks intercalated with andesite lavas and lacustrine beds on the basement of Paleozoic formations and Mesozoic acidic volcanic rocks.

Four large slope failures, Matsukoshi, Kiyotaki, Ontake, and Takigoshi failures, were associated with the earthquake shock causing the loss of 29 lives. The failures were concerned with the weathered volcanic ash, pumice, scoria and/or tuffeceous lacustrine layers.

Matsukoshi failure occurred on a village terrace and its scale was about $150 \mathrm{~m}$ wide, about $230 \mathrm{~m}$ long, the maximum depth of slide was about $40 \mathrm{~m}$, and the total failure volume was $290,000 \mathrm{~m}^{3}$. The sliding material ran up on the other side slope carrying with it a ready mixed concrete plant up to $30 \mathrm{~m}$ from the river bed.

Kiyotaki failures consisted of five failures, which occurred on the foot slope of the mountain. Each failure was on a scale of about 50-100 m wide, $30-50 \mathrm{~m}$ long and 5-10 $\mathrm{m}$ in depth. The slip planes were in the weathered pumice and/or ash layers.

Ontake failure was inferred to have occurred in five blocks consecutively on the southern flank of Mt. Ontake at an altitude between $2550 \mathrm{~m}$ and $1900 \mathrm{~m}$. The scale of failure was about $0.4-0.6 \mathrm{~km}$ wide, about $1.5 \mathrm{~km}$ long, the maximum depth of slide was $150 \mathrm{~m}$, and the total volume was about $36,000,000 \mathrm{~m}^{3}$. The slip plane was in the highly weathered pumice and scoria layers. The failure material turned into a gigantic debris flow and traveled the valley with a thickness of about $40-90 \mathrm{~m}$ at the average rate of about $20 \mathrm{~m} / \mathrm{s}$. The material flowed down about $8.5 \mathrm{~km}$ along the valley and flowed into the main stream of the area, forming a vast sedimentary plain of $100-400 \mathrm{~m}$ wide and $30-40 \mathrm{~m}$ thick over a distance of about $3 \mathrm{~km}$. Part of the earth and rocks spilled over several terraced ridges on the opposite side of the failure slope and at the corners of the valley, and flowed into other valleys. The debris flow consisted of crushed pyroclastics and lava blocks and its surface was undulated during the flow.

Takigoshi failure occurred in the lacusrine sandy soils intercalated with volcanic ash and pumice layers. The scale of failure was about $120 \mathrm{~m}$ wide and about $50 \mathrm{~m}$ long, the maximum depth of slide was $50 \mathrm{~m}$, and the total volume was $500,000 \mathrm{~m}^{3}$. The material flowed about $1 \mathrm{~km}$ and formed a fan-like sedimentary plain on the artificial lake. The failure was inferred to have occurred by liquefaction of the sandy soil.

The failures indicate the importance of geological distribution of highly weathered volcanic ash, pumice, scoria, and/or tuffeceous lacustrine layers for the occurrence of earthquake-induced slope failures and successive flows.
\end{abstract}

\footnotetext{
* 東海大学海洋学部海洋土木工学科

**建設基礎調查設計事務所
**** 新潟大学積雪地域災害研究センター
****** 国土庁土地局国土調查課




\section{1. まえがき}

1984 年 9 月 14 日午前 8 時 48 分に発生した長野県西部 地震（ $M=6.8 ）$ は, 図-1 に示すと招り中部日本を中心 に震度 II ～VI の地震動をもたらした。気象庁発表によ る本震の震央は $35^{\circ} 49.3^{\prime} \mathrm{N}, 137^{\circ} 33.6^{\prime} \mathrm{E}$, 震源の深さは $2 \sim 3 \mathrm{~km}$ のごく浅いところであった。本震に続いて震央 付近の東西約 $15 \mathrm{~km}$ 、南北約 $5 \mathrm{~km}$ の範囲で多数の余震 が記録されたが，中でも 9 月 15 日の $\mathrm{M}=6.2, \mathrm{M}=5.6$ 特よび 10 月 3 日の $M=5.5$ の余震が此較的大きなもの であった1)。

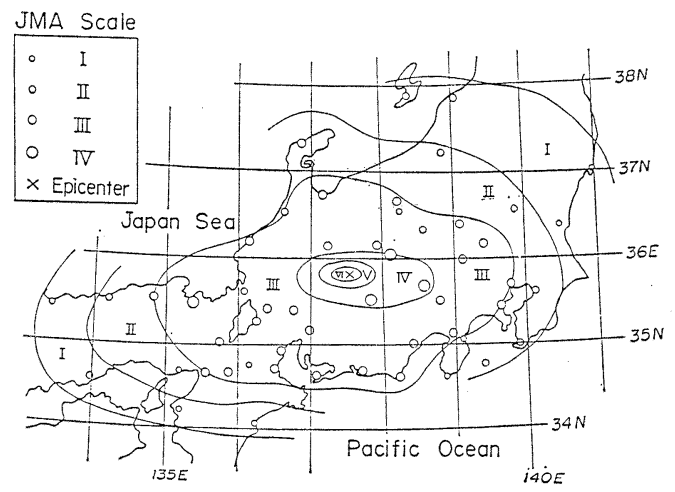

図-1 長野県西部地震の震央と震度分布（気像序発 䒾のデータより作製)

震央は活火山である御算山（標高 $3063 \mathrm{~m}$ ) の南東約 $10 \mathrm{~km}$ の位置にあり, 本震による炎害は震央を中心に半 径約 $10 \mathrm{~km}$ の比較的せまい範团で発生した。御岳火山 に由来する安山岩質溶岩, 火山砕屑物, 火山灰なぞから なる王滰川左岸山地に拁いて多数の斜面崩壊が発生し， これによって 29 の人命が失なわれた。

第四紀火山噴出物の分布地域は国土の約 $1 / 5$ を占めて 扤り, 地震によってこの種の崩壊がたびたび起こる可能 性がある。本論文では，今回の地震による四つの主な斜 面崩壊の特徵を述べ, 土塊の崩落, 移動和よび堆積の各 過程で生起する諸現象の特殊な性格を示した。これは火 山山地での地震による土砂災害の軽減を考える上で堆積 岩, 変成岩, 深成岩なぞの山地とは異なった見方で対処 する必要があることを教えるものであった。

\section{2. 地形・地質}

本地域周辺の基盤山地の山腹傾斜は $20^{\circ} \sim 50^{\circ}$ を示し ている。標高 $2000 \mathrm{~m}$ 以下の火山裙野の部分は, 傾斜 亏 $10^{\circ}$ の緩い斜面を作っている。本地域の年平均降水
量は約 $2000 \mathrm{~mm}$ あり, これによる強い侵食作用と中部 山岳地帯の第四紀に受けた著しい隆起運動とあいまって 御岳山周辺では急速な山体破壊が進行している。谷の深 さは 50 100 m で, 源頭部は標高 $2000 \mathrm{~m} \sim 2400 \mathrm{~m}$ 付 近にまで達している。

御岳火山は更新世に活動を始め, 幾度かの休止期をは さむ独立活火山である。火山体の基盤は, 東側が古生代 ～中生代の砂岩・粘板岩, 西側が濃飛流紋岩からなって 特り,これらは南北方向に推定される断層で接してい る。基盤にのる御岳火山体の基底の直径注約 $20 \mathrm{~km}$ で, 基底から山頂までの比高は約 $1500 \mathrm{~m}$ である。火山体を 構成する地質は 図-2 亿示すように, 更新世前期に形成 された上野玄武岩層, 中期に形成された鈴ケ沢累層・樽 沢累層拉よび後期に形成された王潼累層に分けられ，そ れぞれの問は不整合関係にある2)。

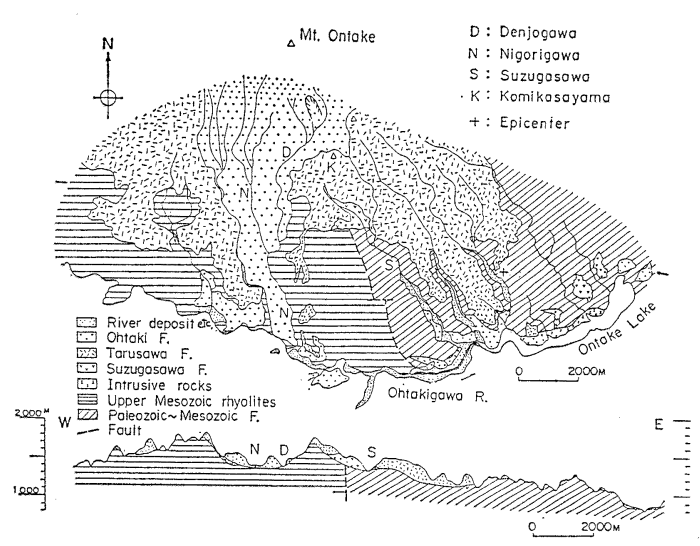

図-2 御岳山南斜面の地質（松本盆地団研木會谷サ ブグループ2) の困に加筆)

これらのらち, 今回の四つの崩壊に関係した地層は更 新世後期の王滝累層である。伝上川付近では本累層は， 下部より木曾谷層, 伝上川溶岩類および奥の院溶岩類に 分けられる。伝上川溶岩類の最下部には，灰白色細粒軽 石層, 粗粒軽石層, 細粒赤褐色スコリア層, 赤褐色〜暗 灰色のやや膠結したスコリア層の順に重なる降下堆積物 が分布する。その上位はスコリア層，スコリア質火山灰 層をはさむ安山岩質の凝灰角磥岩層特よび安山岩溶岩層 からなっている。奥の院溶岩類は御岳火山体上部の斜面 を作って分布する厚さ数 $10 \mathrm{~m}$ の安山岩溶岩である。

\section{3. 地震による斜面崩壊}

今回の地震によって発生した大きな斜面崩壊は 4 個所 で (図-3), 気象庁震度 $\mathrm{VI}$, 水平震度 $0.4 \mathrm{~g}$ に近いか 


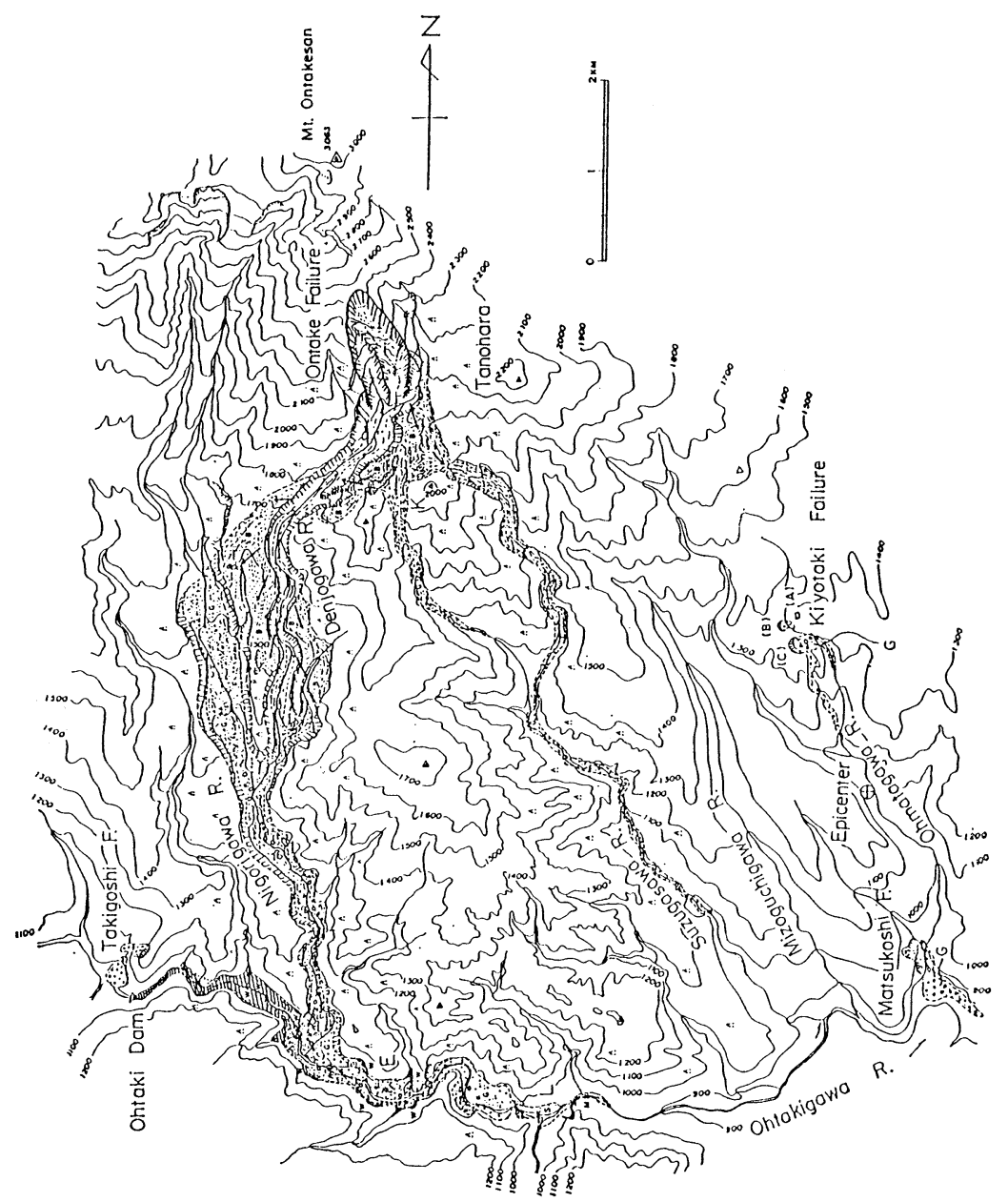

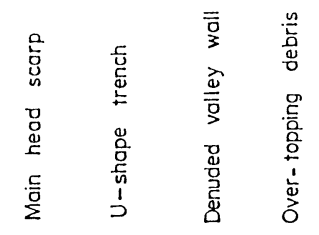

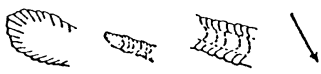


表-1 長野県西部地震による斜面崩壞の地形と地質（粐倉ほか4）に加筆・修正）

\begin{tabular}{|c|c|c|c|c|}
\hline & 松越崩壤 & 清 滝 崩 壞 & 御岳 崩 壞 & 滰越崩 壊 \\
\hline 崩壞土量 $\left(\times 10^{3} \mathrm{~m}^{3}\right)$ & 290 & 100 & 36,000 & 500 \\
\hline $\begin{array}{r}\text { 崩壞前の斜面の傾斜 } \\
\text { (度) }\end{array}$ & 17 & $10 \sim 20$ & 25 & $30 \sim 50$ \\
\hline 斜面の形態 & 凸型の段丘崖 & 凸型の側斜面 & 太った尾根 & 凸型の段丘崖 \\
\hline すべり面の深さ（m） & 40 & $5 \sim 10$ & $100 \sim 150$ & 50 \\
\hline すべり面のかたち & 重復したU型 & 平面型 & U型 & 平面型 \\
\hline 崩壊部分の地質 & 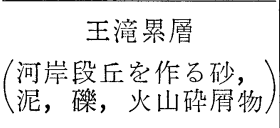 & $\begin{array}{c}\text { 降下堆積物 } \\
(\text { 火山灰, スコリア, } \\
\text { 軽石 }\end{array}$ & $\begin{array}{c}\text { 王滰累層 } \\
\left(\begin{array}{c}\text { 火山砕踷物 } \\
\text { 安山岩溶岩 }\end{array}\right)\end{array}$ & $\begin{array}{c}\text { 王滰累層 } \\
\left(\begin{array}{c}\text { 湖成砂・泥層 } \\
\text { 安山岩溶岩 }\end{array}\right)\end{array}$ \\
\hline 斜面下部の侵食形態 & 河川の側方侵食 & 道路の切取 & 河川の側方侵食 & 河川の側方侵食 \\
\hline
\end{tabular}

るいはそれを越えた地震動があった範囲に分布する。地 表面からすべり面までの深さはそれぞれの崩壊地で異な っているが，すべり面は風化の進んだ軽石層，スコリア 層あるいはこれと物性が類似するより新しい湖成層の部 分にあった。それぞれの崩壊の特徵を 表-1 に示し4), 以下に説明を加光る。

(1) 松越崩壊：この崩壊は震央の南約 $1.4 \mathrm{~km}$ の松越 部落で発生した（図-4）。崩壞斜面は砂砅, 緗まじり粘 土和よび火山灰からなる段丘堆積層（滝越湖成層上部） とこれを覆っている崖錐性の堆積物からなっている。こ の崖錐性堆積物は崩填地上方に急崖を作っている王滝累 層に由来したものである。これらの地層は中〜古生層の 基盤を覆う灰白色〜淡褐色で粘土化の進んだ火山灰層, 軽石層の上にのっている。崩壊後に滑落崖の下端, 段丘 堆積層の基底から大量の涌水がみられたが，それは粘土 化した火山灰層や軽石層が不透水層となり，地下水が段 丘堆積層内に賦存していたことを物語っている5)。すべ り面は粘土化した火山灰層, 軽石層中にあった。

この崩壞によって崩壊斜面上方の平担面にあった数軒 の人家, 木工所特よび県道御岳王滝黒沢線の一部をのせ た約 29 万 $\mathrm{m}^{3}$ の土砂が大又川へすべり落ちた。この崩 壊斜面の対岸河床付近にめった生コンクリート工場は, 流下した崩落土砂とともに河床から約 $30 \mathrm{~m}$ 上方の段丘 面上へ持ち上げられてしまった。

松越崩壊の崩落土砂は大又川を $900 \mathrm{~m}$ 流下し, 牧尾 ダム湖（御岳湖）最上流部の堆砂面上に堆積した。堆積
原上には直径 $1 \sim 2 \mathrm{~m}$ の小規模な流れ山が多数見られ た。崩壊時に御岳湖が満水状態にあったとしたら崩土は 大きな運動量をもって湖水中に突入し, 津波を発生させ たかもしれない6)。

(2) 清滝崩壊: 震央から北北西約 $2 \mathrm{~km}$, 御岳高原南 端の $5 \sim 10^{\circ}$ の緩傾斜の尾根の側斜面で五つの崩壞が発 生した。これらの崩壊が発生した斜面は, 標高 1100 $1300 \mathrm{~m}$ の位置にあり, 厚さ 2 10 m の更新世の火山降 下堆積物に覆われている。御岳有料道路付近で発生した 崩壊 $\mathrm{A}, \mathrm{B}$ 㐨よび C は図-3 に, 崩壊 $\mathrm{A}$ と C の地 質断面は 図-5 に示した。崩壊 B と C は一つの尾根 の東向斜面で起こった。前者は幅約 $100 \mathrm{~m}$, 長さ約 50 $\mathrm{m}$, 深さ $5 \sim 6 \mathrm{~m}$ で, 崩土は斜面中間を横切る御岳有料 道路をのり越え, 小又川の谷底に流れ落ちた。崩壊 C は幅約 $100 \mathrm{~m}$, 長さ約 $60 \mathrm{~m}$ 拉よび深さ $5 \sim 8 \mathrm{~m}$ である。 崩土の大部分は小又川に流れ落ちたが, 南側の一部は傾 斜 $2 \sim 5^{\circ}$ の有料道路上を約 $200 \mathrm{~m}$ 流孔下り, 尾根の西 側にある小又川支流飞落下しさらに谷底を約 $600 \mathrm{~m}$ 移 動して止まった。崩壊 A は御岳有料道路の切取斜面上 方で発生したが規模は小さく, 崩土は有料道路を埋め, 一部は谷底になだれ落ちた。

これらの崩壊のすべり面はいずれる風化した火山灰層 上面あるいは軽石層中にあった。すべり面付近の土は乱 されると流動化するため, 地すべり土塊は本来の降下成 層構造を大きく乱されることなく上部に植生をのせたま ま板状にすべり落ちている。このような火山厕層の板状 

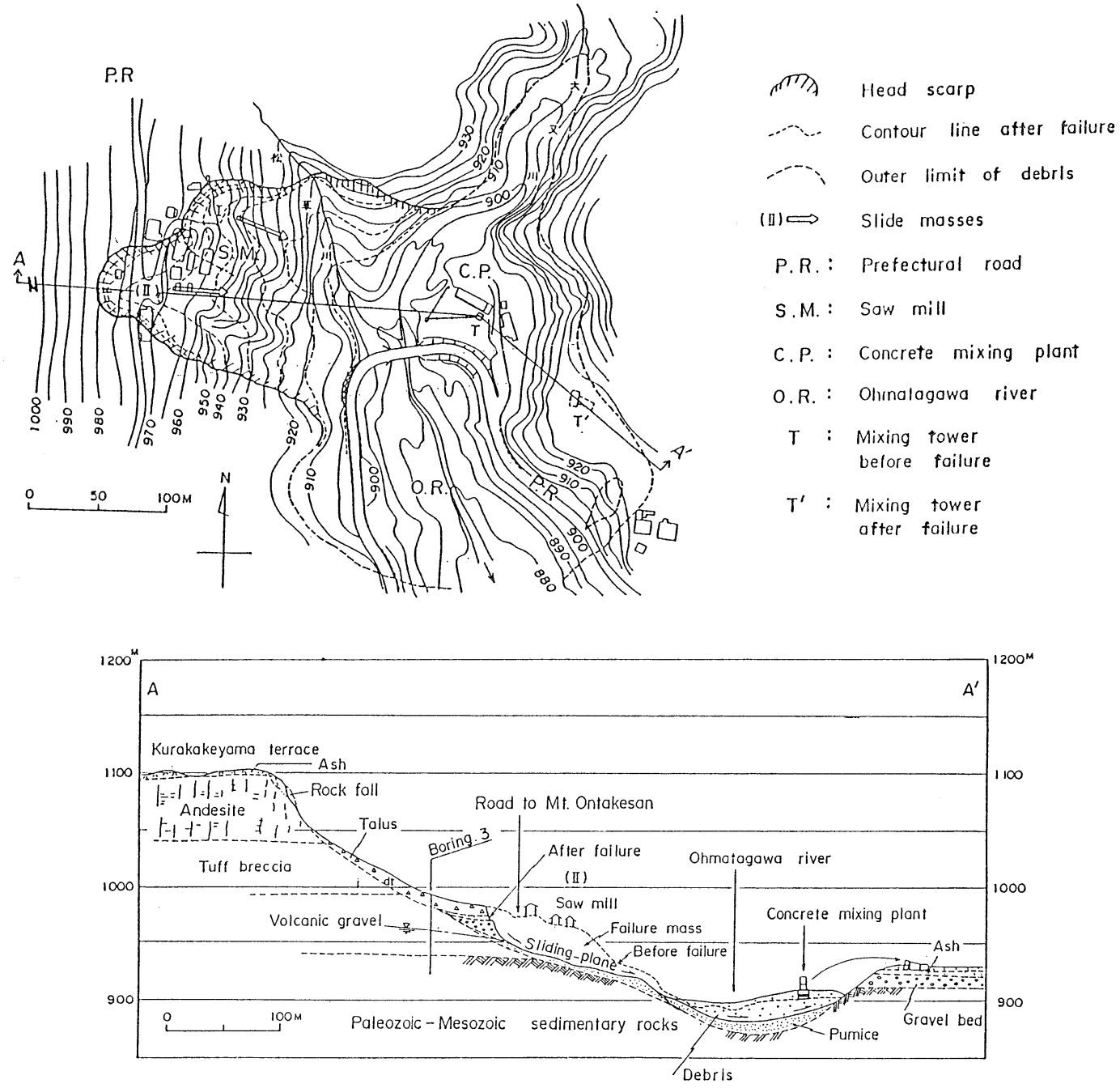

図-4 松越崩壊の平面図および断面図

すべりは 1978 年の伊豆大島近海地震のさい, 見高入谷 付近で多数発生しだ)。この種のすべりは強度の低い地 層が相対的に強度の高い地層の下に埋積され, かつ, こ れらが現地形面とほ济平行に堆積分布しているときに起 こる現象で，板状なだれのそれとよく似ている。

(3) 御岳大崩壊と土石流: 御岳大崩壊は震央の北西約 $8 \mathrm{~km}$, 御岳山 (標高 $3063 \mathrm{~m}$ ) の南斜面で発生した (図-3)。 崩壞は御岳火山南端にある地獄谷火口外輪山から南に延 びる尾根の標高 $2550 \mathrm{~m}$ から $1900 \mathrm{~m}$ までの間が抜け落 ちるよらにすべった。崩壊地は長く延びた馬蹄形を呈 し, 巾 $0.4 \sim 0.6 \mathrm{~km}$, 長さ約 $1.5 \mathrm{~km}$, すべり面の深さは 尾根軸付近で最大 $150 \mathrm{~m}$ に達した。崩壊土量は約 3600 万 $\mathrm{m}^{3}$ (国土地理院計測) であった。崩土の大部分は崩壊
地下端を北東から南西に流れる伝上川を通り，濁川，王 滰川に流出した。崩れた土砂は崩壊地内にわずかに残留 したに過ぎず，擦りきずのある滑落面が広く露出してい た。

崩壊地内の滑落面は単純な馬蹄形曲面ではなく，元の 尾根軸とほぼ平行で西側にずれた位置に北北西に延びる 顕著な谷が出現した。この谷から派生するいくつかの谷 状地形が北北東に延び，滑落面に起伏をつけていた。

本震から 3 日後の空中写真をみるとこれらの谷状地形 の源頭部から水が湧出している状態が読みとれた。本震 の 2 週間後には湧水点は下り, 中央の谷の周辺にかぎら れていた。滑落面の中〜上部はわずかに起伏している が，ほぼ全面に灰白色〜黄白色の細〜粗粒軽石層が露出 


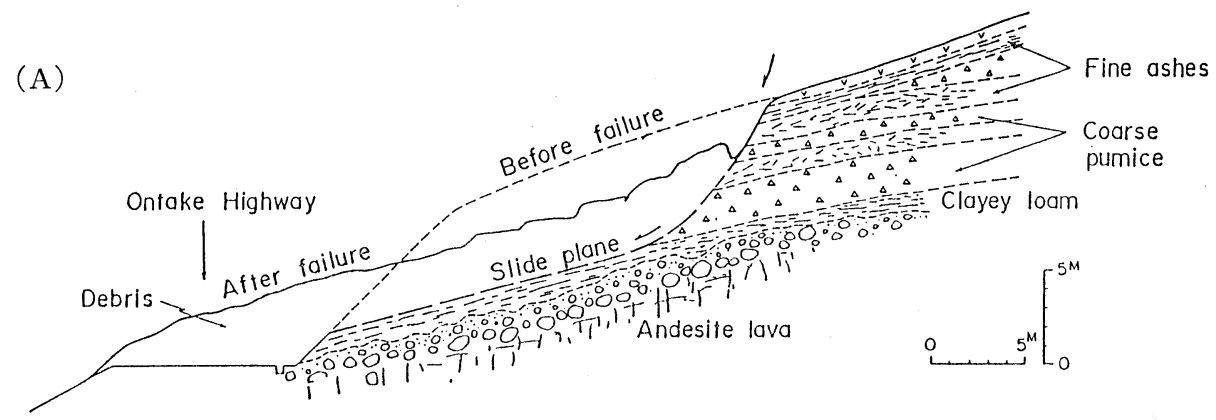

(C)

Alternalion of

fine ashes and pumice

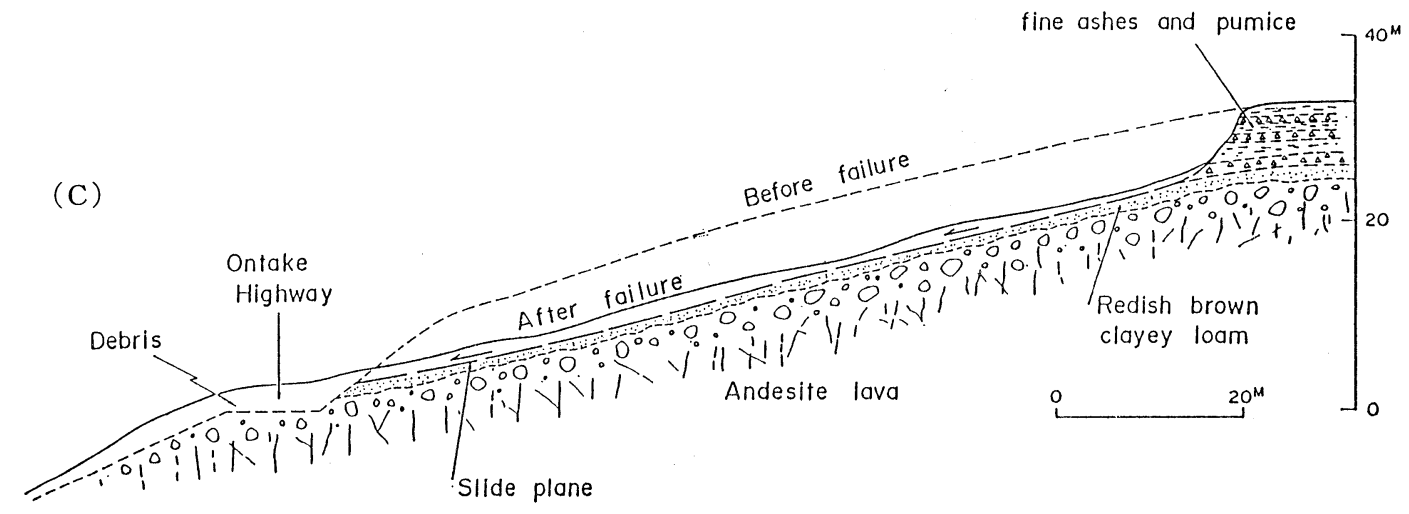

図-5 清滝崩壞（A）および（C）の地質断面図

している。この軽石層表面には複数の方向性を持った擦 痕がみられた。

この崩壊は, 更新世の王滝累層下部層（木曾谷層）に 刻及込まれた古い谷地形を埋積した王滝累層上部層が， 古い地表面を覆うぜい弱な降下堆積物層を境にすべり落 らたものである。

王滝累層上部層は，下位の火山灰，軽石，スコリアな どの降下堆積物層（厚さ $30 \mathrm{~m}$ 以下）と上位の御岳火山 から噴出し斜面に沿って流下・堆積した火山砕屃物, 安 山岩熔岩などの互層（厚さ $60 \sim 120 \mathrm{~m}$ ) に分けられる。 基底部には厚さ $0.2 \sim 2 \mathrm{~m}$ の灰白色を呈する砂質軽石層 (千本松軽石層と呼ばれている2) とこれに漸移する厚さ の変化のはげしい黄白色〜淡黄褐色を呈する粗粒軽石層 が古い谷地形を覆って分布する。これらはともに変質が 進及，指頭ですりつぶすと粘土粒化する。これらの上位 にあるスコリア層 (S-0 スコリア層 $\left.{ }^{2}\right)$ は崩落崖下部に 露出し, 厚さ $3 \mathrm{~m}$ 以上, ところによって $15 \mathrm{~m}$ に達す る。スコリア層の下部は赤褐色を呈し粗粒で緩いが上部 は赤褐色〜暗赤灰色を呈し中〜粗粒でやっ締っている。 スコリア層の直上を覆う地層は火山灰、火山砕屑物，角
羱状溶岩などが入り混った安山岩層で，崩落崖の西側で 厚く $60 \mathrm{~m}$ 以上に達する。最上部には黄褐色の火山乍層 を挟む 2 枚の安山岩溶岩層（全体の厚さで $30 \mathrm{~m}$ 以下） が覆っている。

御岳大崩壞は，すべり面の位置が深く，尾根部が尾根 軸とほぼ平行に抜け落ちるようにすべっていることが大 きな特徴である。崩壊後の滑落面の地形から判断して,

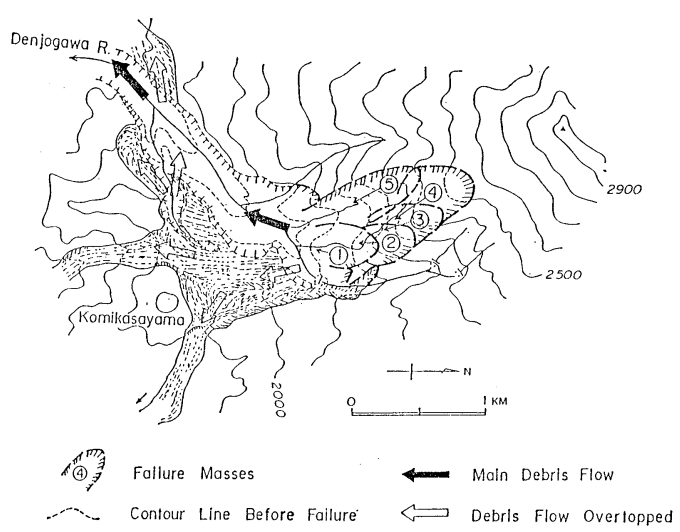

図-6 御岳崩壞の各ブロックと崩土の流動方向 
崩壊部は 図-6 に示すよらに五つの崩壊ブロックに分け ることができる8)。これらは崩壊主要部を構成する尾根 の下部から上部へ (1) (4) の順にならび，(5) ブロックは 尾根の西側にあった古い崩壊地の源頭部が, (3)および (4) ブロックの崩壊にともなって副次的に崩れたものであろ う。大きな崩壊を起こした東側尾根中部〜上部の (2) (4) ブロックのすべり面の大部分は, 細粒〜粗粒の軽石 層内に位置している。

崩壊の発生順序について大草ほか8 (2滑落面の地形お よび伝上川左岸に溢流・散乱した土砂の起源から考光 て，下部から (1)〜 (4) の順にわずかな時間ずつ遅れて発 生したものと考觉ている。酒井 ${ }^{9)}$ は本震の衝撃で以前か ら崩壊が拡大しつつあった伝上川右岸の尾根先端急斜面 が，一次崩壊（崩壊土量約 400 万 $\mathrm{m}^{3}$ ) を起こし，その 後ほとんど時間をおくことなく強振動の継続時間中に上 部が二次崩壊したと推定している。一方，粐倉ほがは， 地震動による斜面の安全率の低下は千本松軽石層をすべ り面とする (2)〜 (4) ブロックで著しく，上方からの荷重 に (1) ブロックの摩擦抵抗が抗しきれずに遅れて崩壊し たと考劣ている。

本震が発生したとき田の原の御岳神社社務所付近にい た皆戸 勉氏の証言「地震のゆれ始めと同時に百雷の軲 くようなものすごい大音響が聞こえた。外を見たが霧の ため崩壊状況は目撃できなかった」が一つの手がかりを 与觉 ${ }^{10)}$ 。

皆戸 勉氏が聞いた轟くよらな大音響は，単発でなく ある時間続いていたが最初の音は斜面の最初の破壊に対 応することにまちがいがない。その後の音は，斜面の破 壊音だけでなく滑落する崩土の衝突音，樹林を圧潰する ときの音などが入り混っていたであろう。

音だけでは崩壊場所，順序を特定できないが，崩壞は 本震の主要動にわずかに遅れて発生し, 主要動の継続時 間中 (10 数秒程度か) にすべての崩壊ブロックが崩落 し始めたと考えてよいであろう。

崩壞の原因として藤田ほが る赤褐色スコリア層の液状化をあげ，川上ほか ${ }^{11)}$ は千本 松軽石層の液状化，クイッククレイ化をあげている。こ れに対し石原ほか ${ }^{12)}$ ・後藤ほか ${ }^{13}$ は, 千本松軽石層の風 化・粘土化が進み，土の内部摩擦角が低下していたため 地震による水平加速度で容易に崩壊が発生したと考えて いる。崩壊の原因についての著者らの考えは各々異なっ ているが，すべり面となっている細粒軽石層，粗粒軽石 層，スコリア層などの降下堆積物層の本来的に持つ堆積 特性, 物理特性が崩壊の素因として深く関与していると
考える点では共通している。これらの地層は多孔質でも ろく, 高い含水比（しばしば液性限界以上の自然含水 比）を示し，一たん乱されると液状化する特徵がある。

御岳山南麗では $0.4 \mathrm{~g}$ を越える水平加速度があったも のと推定されて和り ${ }^{1)}$ ，地震の水平加速度で斜面の安定 性が失われ，崩壞したとする石原らの考えは首肯でき る。地震動による孔陌の多い土粒子の再配列あるいは土 粒子間の骨格構造の変形は当然あったにしても，これが 直接的に液状化につながり崩壊に至ったという確証は今 のところない。重要なことは土粒子あるいは土粒子間の 骨格構造がせん断破壊されることによって生じた余剩の 水が，すべり面付近の土を低粘性の液状体（潤滑剤）に 変化させ，崩落土塊を高速で滑動させることを可能にし たことである。

崩壊地対岸の斜面に飛散した岩塊の分布から堀内 （1981）の式を用いて逆算すると (4)ブロックの落下速度 は 70 75 m/sec 程度と考えられる。崩土がこの速度を 得るためにはすべり面の動摩擦係数は極めて小さくなけ ればならない(後述)。これがすべり面付近に潤滑剤と なり得るものが形成されたと考える論拠で，一種のハイ ドロプレーニング現象とみることができる ${ }^{8)} 。$

崩落した土塊の大部分は崩壊地斜面の下端を北東から 南西に向って刻む伝上川の谷に落ち，巨大な土石流とな って流下した。この土石流の本流は伝上川から濁川に入 り，柳ケ瀬地点で王滝川に流出しここに広い土石流堆積 原を作った。柳ケ瀬下流約 $1 \mathrm{~km}$ の県道にいた恵工電設 （株）田中亮治氏が聞いた大音響を，土石流が濁川王滰 川合流点手前の屋根に突当った時の音とすれば，ここま での土石流の平均流速は, 約 $20 \mathrm{~m} / \mathrm{sec}(8.5 \mathrm{~km} / 7$ 分) に 達したものと推定される10)。

崩壊ブロック (4)の崩落土塊は, 先行した (1)〜 (3) ブロ ックの崩落土塊が滑落面を平滑化しすべり面に潤滑剤と なる液状体の薄層を形成していたこと, 崩落土塊の落下 高が $350 \mathrm{~m}$ 以上あったことなどのため大きな運動エネ ルギーを持って落下した。崩壊地下部には崩土の落下の 方向にやや斜交して北から南へ傾斜する尾根状残丘（崩 壊ブロック (1) の東翼に削り残された部分）がある。崩 壊ブロック (4) の土塊はこれに突当り，これを跳躍台と して土塊の上半部は伝上川を跳び越えて対岸 (左岸) の 田の原から小三笠山北方に延びる緩傾斜面上にのし上げ て飛散した。この崩土は緩傾斜面を覆う樹林帯を押しつ ぶし，一部は小三笠山の北および西の鞍部をのり越えて 鈴ヶ沢に流入したが大部分は緩傾斜面を刻む小谷を通っ て伝上川に戻り，さらに先行して伝上川の谷を埋めて 
いた崩土の上を横断して右岸の伝上川と濁川の間の台地 上まで達した（図-6）。小三笠山北側の緩傾斜面上に堆 積している崩土は, 面積約 $0.3 \mathrm{~km}^{2}$, 厚さ $0.5 \sim 5 \mathrm{~m}$ で, 径 $4 \mathrm{~m}$ 以下の安山岩角砅を主とした粗粒土（火山灰, スコリアを含む）よりなり，表面に灰色〜赤褐色〜黄茶 褐色を呈する様々の色の縞模様がみられる。これは緩傾 斜面上を覆う火山灰層をすべり台として高速で移動した 崩落土塊が，それ自身の外縁部を削り落しつつ流れたこ とを示唆している。伝上川左岸にのし上げた崩土が主と して (4) ブロックのそれであると判断した根拠は，飛散 している安山岩角磕が崩壊地斜面の最上部に分布する板 状節理の発達した伝上川溶岩類の岩塊が多いこと, 崩土 に混入している表層土壞中に高山性～亜高山性のハイマ ッ，矮性のダケカンバやナナカマドなどがみられ，これ らは少なくとも標高 $2400 \mathrm{~m}$ 以上汾分布する植生を示す るのと考光られるからである。

また，伝上川左岸斜面に飛散した岩屑が伝上川の谷を 跳び越兄るためには，射出仰角を $5^{\circ}$ とすると $70 \mathrm{~m} / \mathrm{sec}$ 以上の射出速度を必要とする。るし (2) (4) ブロックが 全体としてすべった場合には $50 \mathrm{~m} / \mathrm{sec}$ 程度の射出速度 となり，射出仰角が $15^{\circ}$ 以上にならないと崩土は伝上川 の谷を跳び越すことができない。以上の諸点から御岳大 崩壊はいくつかの崩壤ブロックに分かれ，数秒程度の時 間差を置いて下部から順に崩壞したもので，伝上川左岸 斜面にのし上げた崩土は，高い位置にあり大きな落下速 度を持った (4) ブロックに由来していると判断できる。 また (4) ブロックの崩土は, 高速であったが故にハイド ロプレーニング現象を起こし, 伝上川左岸緩傾斜面上を 覆う樹林帯を長さ $1.5 \mathrm{~km}$ 余にわたって破壊し，小三笠 山西方の比高約 $40 \mathrm{~m}$ の鞍部をのり越光ることを可能に したのである。これには左岸斜面の最上部に分布する火 山灰層の土性が重要な役割をはたしている33。

崩壊地から落下した崩土の大部分は，斜面下端を刻む 伝上川（河床勾配：1/7.5） 飞流入し，巨大な土石流と なって谷壁を削りながら約 $5 \mathrm{~km}$ 突進し，源を御岳山南 西の地獄谷に持つ濁川に流出した。伝上川は緩く南に傾 く火山裙野斜面を刻む深さ $80 \sim 120 \mathrm{~m}$, 谷底巾 $40 \sim 70$ $\mathrm{m}$ の谷で, 名産の七ノキを含む天然の針広混交林が緩斜 面や谷壁を覆っていた。伝上川を流下した土石流の本流 は，谷底はもちろん谷壁の大部分の植生をはぎ取り岩盤 をも削って，氷河侵食によるU字谷と極めてよく似た地 形を作りだした。谷底部には滑らかに削られた岩盤が広 範囲に露出し，土石流堆積物はほとんど残っていない。 土石流によって侵食された谷壁下部や谷底部の岩盤面
には，流心之平行な擦痕が無数にみられ，軟質な岩盤 （凝灰岩, 凝灰角磼岩など）が撰択的に深く光ぐり取ら れている。一方, 谷壁上部では水平方向の擦痕は活とん ぞみられず，むしろ土砂の落下による縦方向のガリ一侵 食地形が顕著である。

谷の属曲部や狭さく部では, 土石流の流れが阻害され るため堰上げが起こり, 土石流が谷壁をのり越え溢流し ている。崩壊地下端から約 $2 \mathrm{~km}$ 下流, 伝上川が南西か ら南東に曲流する地点では特に大規模な土石流の溢流が あり，伝上川と濁川の間にある高さ約 $80 \mathrm{~m}$ ， ウ $500 \sim$ $800 \mathrm{~m}$ の伝上川右岸台地をのり越光, 数 100 万 $\mathrm{m}^{3}$ の土 砂が濁川に流入した。またこれより約 $600 \mathrm{~m}$ 下流の伝 上大滝直上流の属曲部では, 河床からの比高 $60 \sim 70 \mathrm{~m}$ の伝上川左岸台地上飞溢流し, 約 $1.5 \mathrm{~km}$ 流れて再び伝 上川に戻った。

伝上川を流下した土石流の流速については芦田ら ${ }^{14)}$ は, 崩壊地下端で崩土が得た流速 $50 \sim 60 \mathrm{~m} / \mathrm{sec}$ を減ず ることなく濁川合流点まで流下したと見積っている。著 者らは, 伝上川の直線状の谷の部分での崩土の流速は各 々の崩壞ブロックの落下速度が異っても平均的には 50 $\mathrm{m} / \mathrm{sec}$ 程度の速度で流下したであううと考兄ている。

伝上川から濁川に流出した土石流本流は, 濁川の谷の 屈曲部, 狭さく部で流れが阻害されて間けつ的な流れに 変り, 平均流速は $15 \mathrm{~m} / \mathrm{sec}$ 程度に低下したものと堆定 される。濁川の河床勾配は平均 $1 / 18$ (約 $3.5^{\circ}$ ) で伝上 川のそれと比べてかなり緩く, 流れに対する制動要素が 多い。

伝上川では土石流による谷壁の侵食が䫓著であるのに 対し, 濁川では谷の広い部分の土砂の堆積と谷の狭い部 分の侵食が交互にみられる。攻撃斜面側への土石流のは い上りは非攻撃斜面に対し $20 \mathrm{~m}$ 程度の高さまでしか達 していない。むしろ谷の屈曲部や狭さく部の直上流で高 い位置まで樹木が失なわれている。これらの部分では斜 面にへばりついて土砂が残って和り，幹の折れた樹根が 直立したまま土砂に埋もれている場合がある。濁川温泉 付近の谷の広い部分には直径 $40 \mathrm{~m}$ 以上の流れ山がいく つもあり，堆積土砂の厚さも $30 \sim 50 \mathrm{~m}$ に達する。

濁川が王滝川と合流する手前に西から延びる比高約 $60 \mathrm{~m}$ の尾根があり, 谷が東へ属曲している。ここでも 土石流が堰上げられ，上端部が尾根を溢流して王滰川に 直接落下している。溢流した土砂の量は王滰川に堆積し た土砂のオージブ縞状構造のうち溢流部を扇頂とするも のの範囲は狭小であることを考光ると数 10 万 $\mathrm{m}^{3}$ を越 えることはないであるう。 

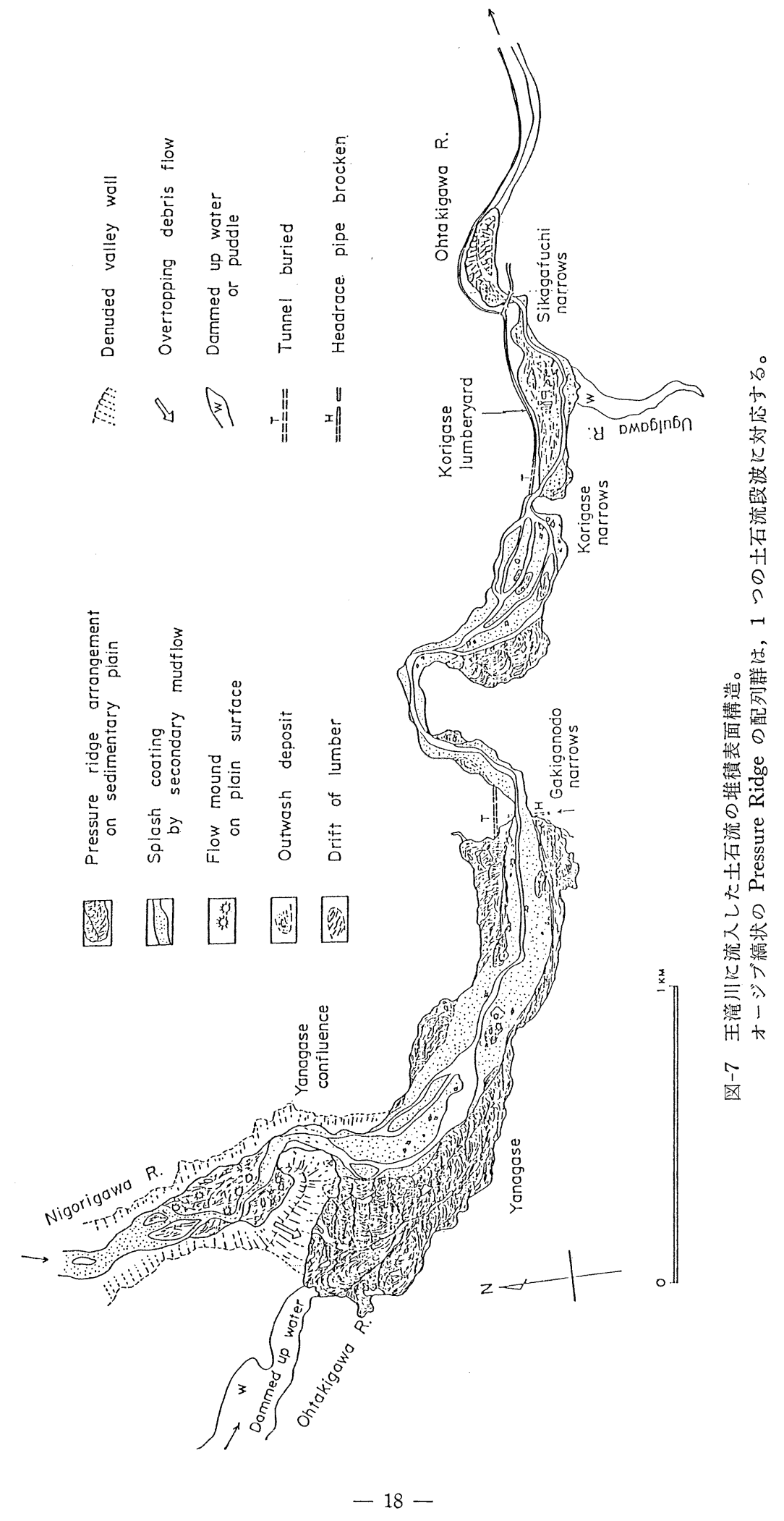
王滝川は広い鍋底形の河谷をもつ緩い勾配（約 $1 / 50 ）$ の谷で, 濁川合流点の下流約 $1.5 \mathrm{~km}$ のところに餓慨ヶ 咽, さらに下流 $1.5 \mathrm{~km}$ のところに氷ケ瀬の両狭さく部 がある。王滝川に流出した土石流は, 水ケ瀬狭さく部ま での約 $3 \mathrm{~km}$ の河床を埋めつくし, 巾 100 400 m の堆 積原を形成した。濁川の合流点付近に堆積した土砂は, 厚さ最大 $40 \mathrm{~m}$ 飞和よび王滰川を堰止め, 王滰川上流約 $2.5 \mathrm{~km}$ にある王滰ダムまで達する貯水量約 130 万 $\mathrm{m}^{3}$ の 湖を形成した。

王滝川河谷に堆積した土石流堆積物は 2500 万 $\mathrm{m}^{3}$ 以 上と推定されるが，餓飢ケ咽トンネル西方にいてこの土 石流を目撃した田中亮治氏（前出）は，1）最初の䪇音で 危険を感じ，山にか汀登ったが最初に来た土石流は白茶 けた信州みそのような色で，段波状に三つぐらい押しよ せてきた。2）それらの段波は走るというよりも飛ら゙よ らで，山の斜面に突き当ると躍跳び時速 $100 \mathrm{~km}$ 以上 あったと思った。3）山の上に逃げ，濁川と王滰川の合 流点左岸の尾根の上から濁川を見たとき，赤っぽい巨大 な土の塊がいくつも流れるというょりもすべるように飛 んでいった。4）これらの土塊の流れる時に発する䡴音 は同日の 12 時ごろまで聞兑ていた……証言している (建設省土木研究所の聞取り資料による)。

これらの証言から土石流の先端部は崩填発生後 $6 \sim 7$ 分後に目撃地点に達しているが，土石流はとの後数時間 にわたって段波状に流下していたことがわかる。

王滝川に流出した土石流の堆積原の表面には, 直径 $10 \mathrm{~m}$ 以下の流れ山が点在し，オージブ縞状に配列した pressure ridge 群が多数組認められた（図-7)。後発した 土砂流によって流心に近い部分ではこれらの一次表面構 造は消されてしまっているが流出当初は堆積原全表面に 形成されていたと考学られる。これら 1 組のオージブ縞 状構造は，一つの土石流段波に対応している（土砂の二 次的な移動によっても当然形成される)。このような構
造は, 表面の粘性が高く, 内部の粘性が低いパホエホエ 溶岩流によく見られる構造で, この土石流の流れ方をし めす重要な鍵を与えている。

また, pressure ridge の間の溝状地飞多数の小噴砂丘 があり，ここから水を噴き出している（図-8）ことから みて, 堆積物内部に過剩な間隙水圧が生じていたと考兄 られる8)。

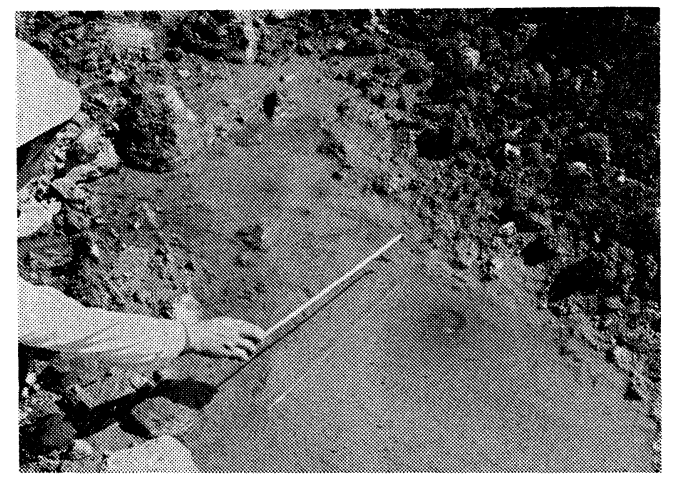

図-8 王滝川の土石流堆積原上の窪地にみられた噴 砂丘の 1 つで直径は約 $9 \mathrm{~cm}$ 。小量の水が湧 出しており周囲定くと地面がゆれ動く。 (9月 28 日撮影)

以上述べた土石流の流下現象㧊よび堆積表面形態から 判断して著者らは 図-9, 図-10 と示すよらな土石流モ デルを考えている。簡単にいえば上部に不飽和の磁質土 層, 下部に飽和した粘性土層があり，下部の粘性土が滑 材となって流下するというモデルである。上部の䃯質土 は谷壁との摩擦抵抗が大きいため下部の粘性土よりも流 速が相対的に小さくなる。また谷の属曲部や狭さく部で は傾面摩擦抵抗が大きくなるための土石流が堰上げら れ，溢流を起こす。堰上げがある程度の高さに達し，堰 上げ地点の上流に和ける下部の粘性土層中の圧力が高ま ると，底部からこれを突き破り上部に硱質土を乗せたま

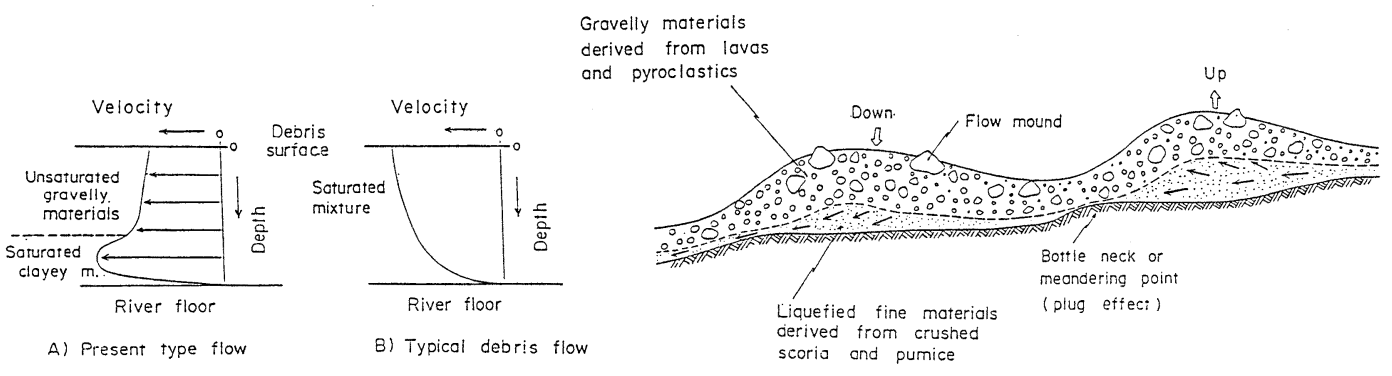

図-9 御岳崩壊にともなう土石流の流下モデル。下部の流動化した部分の流れにのって上部の礫質土が移動 する。屈曲部や狭さく部で土石流の堰上げが起こる。 


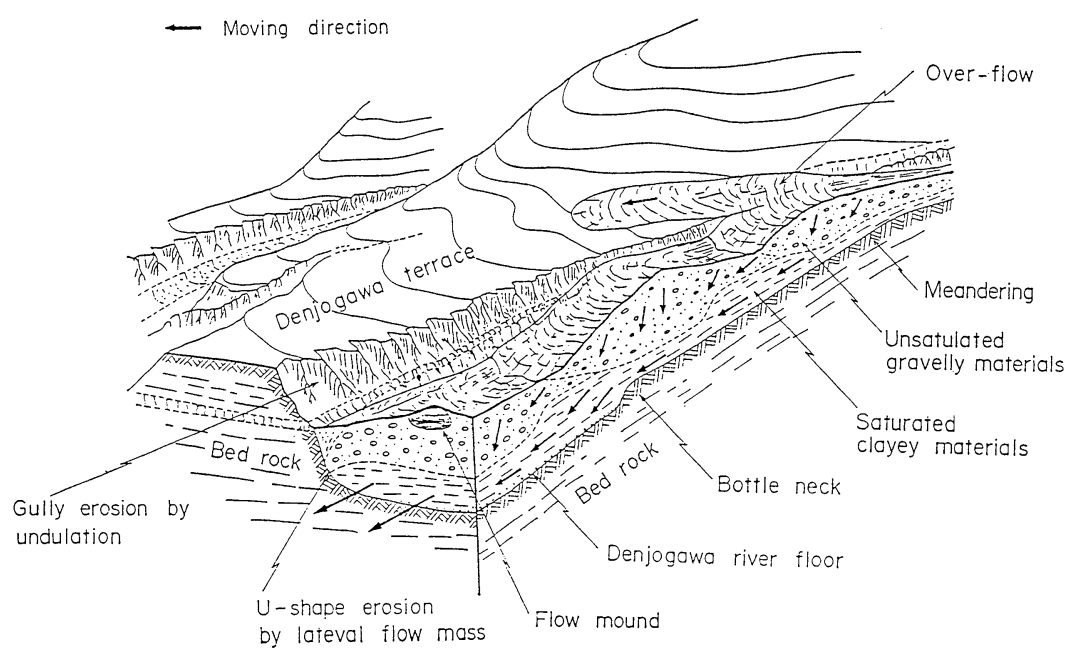

四-10 土石流の流動とこれによる谷壁の侵食を示す模式図。

ま急速に流下する。下部の流動性の高い粘性土層の大部 分が流出してしまうと再び側面摩擦抵抗が増大し, 土石 流の堰上げが始まる。このようにして土石流は伝上川下 流部から濁川・王滰川合流点の間にある $6 \sim 7$ ケ所の屈 曲部や狭さく部で間けつ的な土砂の流れに変光られ，段 波状に流下したものと考光られる。土石流の表面の動き に着目すれば, 谷の屈曲部や狭さく部の直上流では, 土 石流の堰上げと下部粘性土層の流出により表面の上下動 が卓越するのに対し, 直下流では下流に向う水平動が顕 著で流速も大きい。これらの現象は, 谷の地形, 土石流 の土層断面構造和よび各々の土層の性質によって規定さ れている。土石流の層構造（下部の飽和した粘性土と上 部の不飽和磁質土）は崩壊地に和沙る地層の層位的関係 (下部にある軽石, スコリアなどの多孔質火山降下堆積 物と上部にある火山砕屑物, 溶岩などの流下堆積物）を 大局的に維持して叔り，崩落土砂の混合があまり拉こな われていないことを示している。

以上述べたようなモデルは, 御岳山南麓に発生した巨 大崩壊による土塊の崩落一移動一堆積の各過程で現われ た様々な現象（崩土の流速が速く, 崩土の到達距離が大 であること，谷壁の侵食形態が上部と下部で異なってい ること，もろい大きな土塊（流れ山）が乱されることな く $10 \mathrm{~km}$ 以上下流まで運ばれていること, 王滝川の堆積 面上に多数組のオージブ縞状の pressure ridge 配列群が 普遍的に認められること, pressure ridge 上には人が歩 ける程度のかたさを有しているのに内部はぶよぶよで低 い水溜り部に無数の小噴砂丘があり地下水が涌出してい ること，土石流を目撃した田中亮治氏らの証言の内容な
ぞを統一的に説明できる。

このような崩壊の全体像は, 前述の松越・清滰兩崩壊 の外, 十勝沖地震での八戸地区の崩壊, 伊豆大島近海地 震での見高入谷の崩壊なぞ第四紀火山噴出物（特に多孔 質の降下堆積物）の崩壊に共通してみられ，日本の火山 地帯の崩壊形態として普遍性をもったものと考兄られ る。

著者らは，古い地形面を埋積した火山性堆積物が古い ぜい弱面を境にすべり落ちるものを御岳型崩壊，崩土が 崩壊地にあった層構造を維持したまま（通常の土石流の ように土砂の回転・混合を和こなわずに）下部にある水 で飽和した滑材に乗って流下するタイプの土石流を御岳 型土石流と仮称している。

小三笠山北斜面の岩㕌の流動は，高速で突入した粗粒 土塊が在来地盤を乱して潤滑剂を作り出し一種のハイド ロプレーニング現象を起こしたことによるものと考兄て いる。崩壊地対岸の小三笠山北斜面にのし上げた岩屑 は, 主として (4) 崩壊ブロックの崩土と考光られるがそ の突入速度は飛散した岩塊の分布範囲から逆算すると $70 \sim 75 \mathrm{~m} / \mathrm{sec}$ と推定される。これらの岩屑は，針葉樹林 帯の下にある火山灰起源のポドゾル化した土壤 $\mathrm{A}_{2}$ 層和 よびその下位の $\mathrm{B}_{1}$ 層を乱し，流動化したこれらの層を 潤滑剤としてすべっていったのであろう(図-11)。 $\mathrm{A}_{2}$ 層 牡よび $\mathrm{B}_{1}$ 層の自然含水比（120１40\%）は，それらの 液性限界（65～85\%）よりるはるかに高く，指頭ですり つぶすと容易に液状化することが確かめられた ${ }^{3)}$ 。岩原 の流れた斜面の一部には乱された平滑な面に浅い,擦痕の 残る火山灰層が露出しており，地山と岩屠流との間の摩 


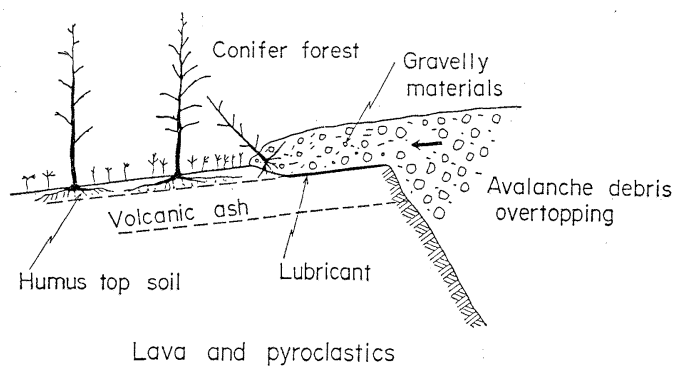

図-11 田の原一小三笠山緩斜面や伝上川右岸台地 上を流れたレキ質土の流動。

表土 (約 $30 \mathrm{~cm}$ ) の下の火山灰層が乱されて 潤滑郕となり，ハイドロプレーニング現象 が起きる。
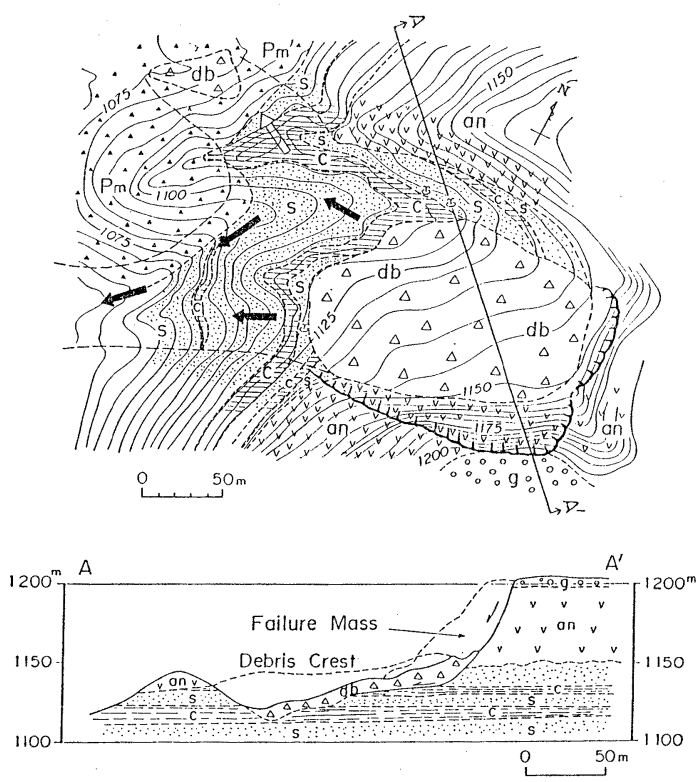

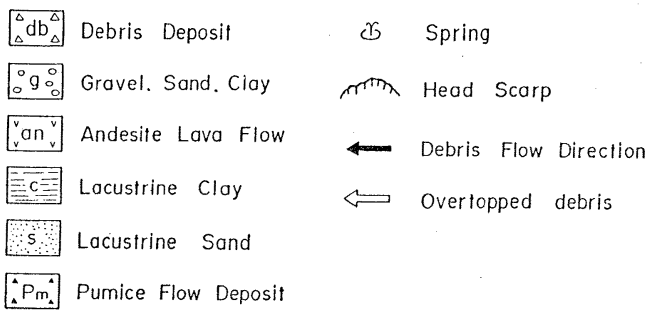

図-12 滝越崩壤地の地質平面図および地質断面図 (粐倉ほか4)の図に加筆修正)

擦抵抗は極めて小さなものでめったことがらかが学る。 田の原・小三笠山付近飞生育する樹木の根系は浅く, 地 表下 $30 \mathrm{~cm}$ 以深にある黄褐色のかたい火山灰層 $\left(\mathrm{B}_{2} \sim\right.$ $\mathrm{C}$ 層) まで侵入した毛根はほとんどみられない。また，
この地城のポドゾル化した土壤の上に生育した森林はし ばしば風倒害を起こすといわれる

このようなところでは樹林帯による突入土砂の阻止効 果は少く，大きなエネルギーを持った崩落土塊によって 容易に広範囲の森林が破壊されてしまったのであうう。 エアクッションにのって岩屑流が斜面を突進したとする 見方もあるが，その具体的な証拠は見いだせなかった。

(4) 滰越崩壊：本崩壊は震央から西約 $8 \mathrm{~km}$ ，標高約 $1200 \mathrm{~m}$ の台地状尾根の北西向斜面で起った。他の崩壊 地と異なりここの地質は火山灰質土を含む湖成層（滰越 湖成層）とこれを覆う安山岩溶岩層および砂磷層からな っていた。すべり面は主としてこの湖成層の中にあっ た。崩壞の規模は幅約 $120 \mathrm{~m}$, 長さ約 $80 \mathrm{~m}$ ，すべり 面の深さ約 $50 \mathrm{~m}$ で, 崩壊土量は約 50 万 $\mathrm{m}^{3}$ であった (図-12)。崩壊土砂は約 $100 \mathrm{~m}$ 斜面をすべった後, 南西 向きの小さな谷に流れこみ王滝ダム貯水域に扇状の唯積 原を形成しだ)。すべりを起こした湖成層は，火山灰， 軽石，スコリアなどを含む砂質〜泥質の成層した末固結 層で，湖成層中のすべり面の傾斜は緩く $5^{\circ}$ 以下であっ た。崩壊は緩い砂質土部分が地震動によって液状化し, 斜面全体の安定を乱したことにより発生した可能性が大 きい。湖成層は一たん乱されると流動性に富む土砂とな るため, 崩土は植生をのせたまま崩壊地未端から約 $1 \mathrm{~km}$ はなれた王滰ダム湖右岸にまで達した。これによる死者 は6人であった。

\section{4. まとめ}

本論文では今回の地震によって震源域を中心に発生し た多数の崩壊のうち, 主要な四個所の崩壊についてのべ た。これらの崩壊は，いずれも更新世後期の火山作用に 関係して形成された未固結の地層が $0.4 \mathrm{~g}$ を越觉る強い 地震動を契機としてすべったものである。

これらの崩壞のうち滝越崩壊は湖成層の液状化による ものと考兄られる。他の三つの崩壊は傾斜堆積した火山 灰層, 軽石層を境にすべっている。これらはそれぞれ異 なった様相を呈するが，いくつかの共通点をあげると， 1）崩壊斜面の平均傾斜は $25^{\circ}$ 以下である。2）すべり 面は冠頭部をのぞいて 10 2 $25^{\circ}$ の傾斜で物括むね直線 状となっている。3）すべり土塊は板状あるいはブロッ ク状に滑落している。4）すべり面は風化の進んだ火山 厕層, 軽石層の中にある。5）崩土の流動性が高く落下 高に対し到達距離が大きいことなどの点があげられる。

松越, 清滰拉よび御岳の三つの崩壊に大きな役割をは たしている風化変質した火山圧層と軽石層の力学特性に 


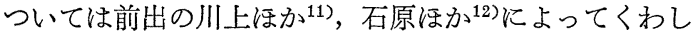
く検討されている。また, 田中 ${ }^{16}$ は松越, 清滰, 御岳の 各崩壞のすべり面となっている火山灰層や軽石層中に八 ロイサイトが含まれていることを報告しており，他の地 震による崩壊の例も合せて風化した火山灰質土の物理的 性質に和よぼすハロイサイトの重要性を指摘している。

すべり面付近の地層ないし土層は清滰崩壊のように不 飽和であっても液性限界を越光る高い自然含水比をしめ すことがある。田の原から小三笠山にかけて緩斜面上を 覆う火山灰質土層に打いても同じことが確認されて特 り，これらの地層ないし土層は一たん乱されると流動性 の高い土に変化することを暗示している。

これは降下堆積物の持つ本来の堆積特性（旧地表面に 沿って傾斜堆積すること，化石風化土層などのぜい弱層 をはさみこんで堆積することなど), 物理化学特性（粒 径がそろって密度が小さいこと, 緎維状, カラメル状で 粒子内の空吵が多いこと, 高温から急冷されているため 化学的に不安定で風化や温泉変質作用を受け粘土化しや すいことなど), 強度特性（粗粒土でありながら含水比 が高く，風化すると容易に粘性土的性質をしめすように なること，セン断されると体積減少を起こすことなど） が崩壊と崩土の流動を性格づける大きな要因となってい ることを示している。しかし，このような厚い火山噴出 物の中に挟采れた弱い降下堆積物層の立体的分布を把握 することは現実問題として極めて困難であるといわざる を得ない。

火山地帯では噴火などによる直接的な土砂災害の危険 性だけでなく，地質形成の過程で埋積されたこのような ぜい弱部に起因する地震時の崩壊の危険性にも十分注意 をはらっていく必要があろう。

\section{5. 謝辞}

本論文をなとめるに当たって信州大学理学部の酒井潤 一博士より御岳火山の地質と層序についての有益な資料 をいただいた。また, 東京大学工学部の石原研而教授, 京都大学防災研究所の奥田節夫教授, 京都大学理学部の 小林芳正教授, 科学技術庁防災科学技術センターの大八 木規夫博士注かから今回の地震に上る崩壊と崩土の流動 に関して示唆に富むかずかずの意見をいただいた。愛知 工業大学飯田汲事教授をはじめとする文部省自然災害科 学特別研究班の方々に大変御世話になった。合せて感謝 と御礼を申し上げる。

\section{文献}

1) 大井田 徹, 山崎文人, 山田 守, 青木治三, 藤井
㦑, 中村 勝, 宮島力雄 (1985)：1984 年長野県 西部地震とその余震活動, 飯田波事編「1984 年長 野県西部地震の地震抒よび災害の総合調査」, 自然 災害特別研究突発災害研究成果 No. 59020202, pp. $11 \sim 20$.

2）松本盆地団研木曾谷サブグループ（1985）：昭和 59 年長野県西部地震による地震災害と御岳山南麓 の地質, 地球科学, 39, pp. 89 104.

3) Okusa, S., Anma, S., Maikuma, M. and Fujita, Y. (1986): Slope failures during the 1984 Naganoken-Seibu earthquake, Central Japan, Engineering Geology Problems in Seismic Areas, Bari, Italy, Proc. 2, pp. 91 103.

4）粐倉克幹, 安田 進, 榊 裕介 (1985)：長野県西 部地震での被災例にもとづいた斜面崩垻予測手法 の検討，士と基礎，33-11 (334), pp. 41 46.

5）藤田至則，鈴木幸治（1984）：昭和 59 年長野県西 部地震に上る地震災害——液状化儿上る斜面崩壤 - , 新潟大学災害研年報, No. 6, pp. 111 116.

6) Boit, B. A., Horn, W. L., Macdonald, G. A. and Scott, R. F. (1975): Geological Hazard, Springer Verlag, p. 135, p. 177, p. 196, p. 242.

7) Okusa, S. and Anma, S. (1980): Slope failures and tailings dam damage in the 1978 Izu-OhshimaKinkai earthquake, Engineering Geology, Vol. 16, pp. $195 \sim 224$

8) Okusa, S., Anma, S. and Maikuma, H. (1985): A gigantic avalanche of earth and rocks in the 1984 Naganoken-Seibu earthquake, Central Japan, 1st. Int. Conf. of Geomorphology, Manchester, U. $\mathrm{K}$. (Proceedings are in press).

9）酒井潤一 (1985)：昭和 59 年長野県西部地震によ る斜面崩壞, 前出 1), pp. 165 178.

10）奥田節夫，奥西一夫，吉岡龍馬，諏訪 浩，横山康 二 (1985): 崩壞土石の流動状況の復元と流動形 態阔する考察，前出 1), pp. 187 198.

11）川上 浩，小西純一，斎藤 豊 (1985)：長野西部 地震における斜面崩壊のメカニズムと軽石層の土 質性状. 土と基礎 33-11 (344), pp. 53 58.

12）石原研而, 吉田喜忠, 中角功, 許海能 (1985): 被災地の土質強度とすべり安定解析. 第 20 回土質 工学研究発表会特別セッション「長野県西部地震 に打ける斜面崩壊の穾態とその教訓」, pp. 37〜 45.

13）後藤恵之輔，愛甲 敬，有沢雄二 (1985)：長野県 西部地震に扮ける大規模土砂崩壊の発生・流下機 構, 土木学会誌, 70-2, pp. 12 18.

14）芦田和男，江頭進治（1985）：御岳くずれに打け る崩土の挙動. 前出 1), pp. 199 205.

15）松井光瑤（1972）：表層に還元現象の認められる 森林土袞について，ペドロジスト， 16，pp. 107〜 110 .

16）田中耕平 (1985)：長野県西部地震飞よる斜面崩 壞の特徴，土と基礎，33-11（334）, pp. 5 11。

（昭和 61 年 2 月 19 日受付, 昭和 61 年 8 月 8 日受理） 